\title{
THE "MUDEJARS" OF SICILY AND HUNGARY
}

\author{
Robert I. Burns, S.I.
}

Muslims organized as free men, not slaves, lived under European governance as semi-autonomous communities in medieval Iberian countries for countries. At the opposite end of the Mediterranean, other Muslim communities endured crusader governance in the Levant. The two situations were unequal, however, as Benjamin Kedar has explained ${ }^{1}$; the crusader governance was brief and precarious, with few resident Europeans and in an antagonistic Holy War framework. For an analogue or term of comparison with Spain's Mudejars, the historian looks rather to Sicily and Hungary.

Neither of those two areas has received its due attention, though promising work is currently going forward in each. For Sicily Henri Bresc has revived interest with his seminal addres in 1979, «Mudejars of the Crown of Aragon and Saracens of Norman Sicily: The Problem of Acculturation» $\rangle^{2}$. Then in 1990 David Abulafia presented an intensive and revisionist study of the decline of Sicily's Mudejars and the transformation of then society in his «The End of Muslim Sicily» ${ }^{3}$. Now a student of Abulafia, Julie Taylor, is completing at Cambridge University in England an archival dissertation on the Lucera colony, the community established by Frederick II Hohenstaufen whan he expelled some 20.000 Muslims from Sicily to isolate them and bind them to the soil.

When James M. Powell of Syracuse University in New York was planning his pioneering work on Muslims under Latin Rule 1100-1300 in 1990, he found it impossible to persuade any Hungarian scholars to contribute a study on then region; they felt the topic there was as yet too undeveloped in

* U.C.L.A. (U.S.A.).

1. KEDAR, «The Subjected Muslims of the Frankish Levant», in Muslims under Latin Rule 1100-1300, ed. James M. Powell (Princeton: 1990), pp. 135-174.

2. BRESC, «Mudejars des pays de la couronne d'Aragon et Sarrasins de la Sicile normande: le problème de 1 'acculturation», in X Congreso de historia de la corona de Aragón, 3 vols. (Zaragoza: 1979-1982), II, pp. 51-60.

3. In Muslims under Latin Rule, pp. 103-133. 
its scholarship. Now however Hungary's Muslims have found a young scholar of their own. Nora Berend submitted her doctoral dissertation at Columbia University in New York in 1996 on «Non-Christians in a Medieval Frontier Society: Jews, Muslims and Pagans in Thirteenth-Century Hungary», as yet unpublished. Professor Berend is currently at St. Catherine's College at Cambridge University in England; she has just published an article on the regulation of clothing for non-Christian minorities in thirteenth-century Hungary, which affords some taste of her findings on Muslims there ${ }^{4}$.

The article's topic is tangential, as dealing with clothing-signs, and general as dealing with Jews, Muslims, and specially Cumans. Its data on Muslims nevertheless catch the eye. All these minorities amounted to less than ten percent of the population in thirteenth-century Hungary. Muslims had been present at the eleventh-century beginnings of the Christian kingdom and had continued to immigrate. We have no charter of privileges for the Muslims, as we do for the Jews; but "these Muslims lived in their own communities and had a collective status, which included rights and obligations". Indeed, their "Legal status did not differ radically" from Christian groups, since the general populace was fragmented into idiosyncratic custom-law units. At least a considerable portion of Muslims assimilated, in clothing and in shaving their beards, to the Christian pattern.

Ecclesiastical complaints indicate clerical concern with the "too favorable status" of Muslims and Jews here, with a general co-mingling. In the thirteenth century they were not the target of organized conversion, though the Cumans were so targeted. For a brief period "at the turn of the eleventh and twelfth centuries, the forced conversion of Muslims became a preoccupation of certain kings", with each Muslim village required to build a church; but that was an anomaly. Papal efforts to impose a red circle to be worn on each Muslim's breast never acquired backing from crown or populace, and never went into effect. Muslims could be found in trade, agriculture, the army, and royal officialdom. They seem to have been as integrated into the Hungarian populace as was possible without the essential religious conversion. Nevertheless these Muslims became "completely converted and integrated by the mid-fourteenth century, without any visible struggle", a phenomenon facilitated by "their becoming increasingly isolated from their coreligionists abroad"s.

4. Nora Berend, «Medieval Patterns of Social Exclusion and Integration: The Regulation of Non-Christian Clothing in Thirteenth-Century Hungary», Revue Mabillon, n.s. 8 (t. 69) (1997), 155-176.

5. Ibidem, quotes from pp. 158-163, 167, 173-175. 
Students of Arago-Catalan Mudejarism are especially interested in the Sicilian model, since that region became part of the wider sphere of the Crown of Aragon from 1285. But the same scholars should have a special interest in Hungary because King Jaume's queen Yoles or Violant (1216-1251) was the daughter of King Andrew II of Hungary, her baptismal name being Andreua. From her marriage to Jaume in 1235 her influence on his person and policies was notable, as he himself describes in his autobiographical Llibre dels feyts. At the culminating sieges of Valencia city and especially Játiva, arguably the two most triumphant moments of his life, Violant was his main counsellor and support. Jaume himself had little experience with Muslims until his military adventures began, while his Hungarian wife had grown up in a society and a court familiar with and congenial with a native Muslim population. The king's actions and policies should be reexamined in light of what we are now learning about this Hungarian background.

\section{ABSTRACT}

Bibliographical remarks about the main trends of recent research on islamic communities living under christian governance in Sicily and Hungary. Its concern to those who are interested in Arago-Catalan Mudejarism.

Key words: Mudéjar, islamic minority Sicily, Hungary, Bibliography.

\section{RESUMEN}

Los mudéjares de Sicilia y Hungría. Comentario bibliográfico acerca de los últimos avances de la investigación en torno a las comunidades islámicas que viven bajo gobierno cristiano en Sicilia y Hungría en la Edad Media. Interés para los estudiosos del mudejarismo catalano-aragonés.

Palabras clave: mudéjar, minoría islámica, Sicilia, Hungría, Bibliografía. 